\title{
The Effects of Educational Videos on Views and Attitudes of Engineering Undergraduate Students
}

\author{
İbrahim Halil ÖZDEMİR \\ Ege University, Graduate School of Educational Sciences, İzmr, TURKEY
}

Firat SARSAR

Ege University, Faculty of Education, İzmr, TURKEY

Özge ANDİÇ-ÇAKIR

Ege University, Faculty of Engineering, İzmr, TURKEY

Received: 10 October 2021 - Accepted: 7 December 2021 - Published Online: 20 December 2021

\section{Abstract}

\begin{abstract}
The usage of videos in undergraduate students' engineering education has gained importance in recent years. Videos, which are used as a supportive tool in traditional engineering education, have become a source of information in online learning environments. The aim of this study is to examine the effects of educational videos on engineering undergraduate students' laboratory applications and its examination of opinions developed within the scope of e-learning. For this purpose, the sample consisting of 50 undergraduate students from the civil engineering department has been used for this research. Pre-test and post-test process conducted within the scope of in this research were resulted in a meaningful difference after the analyses of Paired Samples $t$-Test $(p=0.02)$ was made. This result shows that online learning platforms in engineering education and educational videos positively affect the students' attitude. In addition, it is found out that educational videos affect the learning process as a useful educational source. Moreover, the instructors' educational videos, which are Digital Learning Materials, positively impact the students' motivation during the courses.
\end{abstract}

Keywords: videos, educational videos, laboratory, engineering education.

\section{Introduction}

The technological developments in higher education have also shown their effect on engineering education which is one of the disciplines in higher education. Engineering education in terms of its content and structure takes shape by supporting theoretical information with application studies (Iqbal, Zang, Zhu, Chen \& Zhao, 2014). Technology stands in an important position in engineering education in conveying theoretical information with applicational studies (Zaneldin, Ahmed \& El-Ariss, 2019). The use of developing technology has revealed alternative methods in the source of information about engineering and its transfer (Brame, 2016). One of the alternative methods that have been revealed is educational videos (Pedrotti \& Nistor, 2014; Fernandez et al., 2011).

(C) Authors. Terms and conditions of Creative Commons Attribution 4.0 International (CC BY 4.0) apply. Correspondence: İbrahim Halil Özdemir, Ege University, Graduate School of Educational Sciences, İzmır, TURKEY. E-mail: ibrahimhllozdemir@gmail.com. 
According to Mayer (2009), educational videos are instructional contents that present visual and auditory environments together. Fiorella and Mayer (2018) claim that educational videos emerge by combining the visual and auditory environments in order to reach information. Educational videos in engineering education have a supportive role for the instructors during definitions.

In addition to this, educational videos enable students to recognize and visualize the information (Shephard, 2003). According to Dharmadhikari (2011), the use of educational videos in engineering education has a positive effect on increasing the educational experience. In engineering education, the traditional ways to convey theoretical information into application studies may be limited. Figure 1 shows the limitations of traditional learning environments in engineering education (Domingues, Rocha, Dourado, Alves and Ferreira, 2010; Iqbal, Zang, Zhu, Chen \& Zhao, 2014).

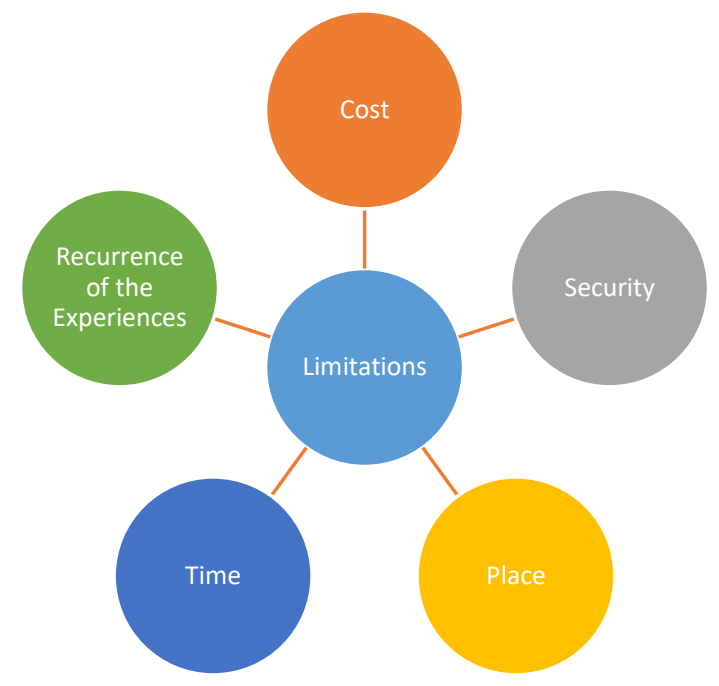

Figure 1. Limitations of traditional education settings in engineering education

The educational videos in engineering education combine visual and auditory environments to convey theoretical knowledge and applications and play an important role in removing limitations presented in Image 1 . The structural characteristics of the educational videos enable them to be free from time and place and their reusability provides savings in terms of cost (Marques, Quintela, Restivo \& Trigo, 2012).

Besides these, the use of educational videos in engineering education creates a safe environment by eliminating the risks that can be encountered during application studies (Jackson et al., 2013; Zaneldin, Ahmed \& El-Arris, 2019). According to Simo et al. (2010), the use of educational videos in the engineering field makes contributions to the collaborative work, between the instructors and students. In the light of collaborative work there may be developments in engineering education and interdisciplinary studies.

The use of educational videos in engineering education also brings many advantages. These advantages were stated as follows (Dharmadhikari, 2011; Wagner, Laforge \& Cripps, 2013; Violante \& Vezzetti, 2014; Carbonell \& Pons, 2014):

i. The educational videos used in engineering education can be reused due to their structural nature.

ii. The videos can be watched at any time.

iii. The educational application videos give freedom of place to the individual. 
iv. The use of video equipment has a positive effect on the students' motivation.

v. The educational videos in engineering education may have a positive impact on the student's motivation.

vi. With the use of educational videos, the instructional content can be transferred to much more students.

The studies about the use of educational videos in engineering education have reached a conclusion that educational videos provide freedom of place to the instructors and students (Ferreira, 2004; Toto \& Nguyen, 2009; Dharmadhikari, 2011; Violante \& Vezzetti, 2014; Carbonell \& Pons, 2014; Saar, Kusmin, Laanpere, Prieto \& Rüütman, 2017). In the light of the studies, it was realized that the use of educational videos in engineering education is crucial for individual learning (Granio \& Rasterio, 2018; Violante \& Vezzetti, 2014; Carbonell \& Pons, 2014; Chao, Chen \& Chuang, 2015). The studies conducted with the engineering students about the educational videos have shown that they have an important impact on motivation and attitude (Månsson, Löfgreen \& Warfvinge, 2017; Dharmadhikari, 2011; Kay \& Kletskin, 2012; Rhema \& Miliszewska, 2014; Chao, Chen \& Chuang, 2015).

In engineering education, in order to develop an educational video, it is necessary to follow a five-staged roadmap. In a linear structure, these five stages are; planning, saving, editing, content production and sharing (Kybartaite, Nousiainen \& Malmivuo, 2013).

\subsection{The importance and the purpose of the study}

As a result of the analysis of the literature studies, it is seen that the use of educational videos and outside class works in engineering education is not sufficient. (Kerr, 2015; Herela, Knutas, Vanhala \& Kasurinen, 2017; Maclaren, 2018). Moreover, more studies are needed to be done which will take students as a target audience (Yang \& Pakala, 2017; Nguyen et al., 2017; Kleftodimos \& Evangelidis, 2018).

The purpose of this study is to examine the effects of educational videos on engineering undergraduate students' laboratory applications and review their opinions. For this purpose, the answers to the questions below were sought:

(1) Do the educational videos which were developed within the scope of e-learning have an impact on the attitudes of engineering undergraduate students toward e-learning?

(2) How are the opinions of engineering undergraduate students toward educational videos which were developed within the scope of e-learning?

1.2 Developing a student-centered online learning environment for the laboratory applications in engineering education

In this study, it has been planned and aimed to contribute to a process of enriching an existing course with technology and integrate it into a ready curriculum. Therefore, the curriculum was reviewed again considering the instructional design steps, the needs have been updated, the necessary arrangements have been made in the design process and the materials have been developed. The developed materials were applied, and the assessments have been made. The development stages of the materials are shown in Figure 2. 
İ. H. Özdemir, F. Sarsar \& Ö. Andiç-Çakir - The Effects of Educational Videos on Views and Attitudes ...

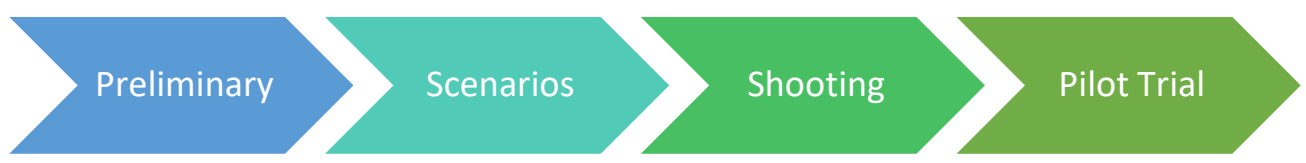

Figure 2 The steps of developing educational video materials

\subsubsection{Preliminary}

In order to increase the visual effectiveness and have a more effective preparation for the materials, a technology that contains a green box set has been used. The green box, green curtain and green curtain legs to enable portability, light systems in the front and the sides to prevent shadows, video cameras to create quality video recording, foot brackets to fix the camera and microphone systems to improve sound quality were used.

The sets were established to the recording field therefore all the equipment was chosen carefully according to their characteristics. The positioning of the setups was adjusted by the professionals to ensure a quality recording.

All the portable equipment was carefully adjusted inside and outside of the studio to have a quality shooting. The application laboratory in which the experiments will be shot, the necessary permissions and the determination of the people on camera and behind the camera were all prepared by professionals in the preliminary step.

\subsubsection{Scenarios}

In creating the scenarios of the experiments, the application stages of the experiment were transferred into a text in accordance with the related Turkish Standards. The brainstorming technique was used in the creation process.

In the scripting stage, the professionals took care of all the visuals, implementation stages, sounds to be used, input and output videos, the effects, on-camera people and the materials that will be used in the experiment. After the scripting stage the created texts, the flow and visual works were prepared by experts.

\subsubsection{Shooting}

The shooting process was carried out by using the prepared experiment scenarios and sticking to the experiment shooting plan. During the shooting, suitable shooting angles were determined, and light adjustments were made by using the portable light set. The experiment took place in the Ege University Engineering Faculty, in the Application Laboratory of Civil Engineering. There were also professionals behind the camera.

The person on camera who was performing the experiment was selected as an expert. During the shooting of the experiment occupational safety measures were followed. It was ensured that the shooting laboratory will be empty during the shooting period.

The next stage after the shooting is editing the videos. At this stage, video editing was performed in accordance with the scenario. The video editing processes include cutting, mounting, green screen wiping, sound adding, visual adding and creating input and output videos. After the approval of 3 academic members, the edited videos were rendered. 


\subsubsection{Pilot trial}

In the 2018-2019 Academic Year Spring Semester, in the Ege University Engineering Faculty, the experiments in the curriculum were shared via videos with the students who take the Materials of Constructions course. In this context, 5 trial videos which were prepared as Image 4 were uploaded to Web 2.0 which is an interactive video preparation tool and which keeps rating statistics.

Prepared videos were shared with the students with the Learning Management System. The trial process took seven weeks and necessary adjustments were made to create the final version of the video materials.

\section{Method}

In this study, the Mixed Method Pattern was used among the scientific research methods. The Mixed Method Pattern gives a detailed research potential by using quantitative and qualitative data together (Creswell, 2009). In this pattern, the quantitative and qualitative data were seen and used as a whole (Alkan, Şimşek \& Erbil, 2019).

\subsection{Research sample}

The research sample of this study is 50 students who were studying in Ege University Engineering Faculty, Civil Engineering in the 2018-2019 Academic Year Spring Semester. The method used to select the students was simple random sampling. In simple random sampling, all the units in the universe are selected with an equal and independent probability (Büyüköztürk, Çakmak, Akgün \& Karadeniz, 2017).

\subsection{Data collection tool}

In this study, a General Attitude Scale Towards E-Learning for Faculty of Education Students was used as the data collection tool. It was a data collection tool that was developed by Wilkinson, Roberts and While, (2010) and adopted to Turkish by Haznedar and Baran (2012). This scale consists of 20 items and has a Likert type grading. On this scale 1 (Strongly Disagree), 2 (Disagree), 3 (Neutral), 4 (Agree), 5 (Strongly Agree).

The Cronbach coefficient was calculated for reliability estimation of this scale which was adopted by Haznedar and Baran (2012). The alpha coefficient was calculated as 0.93 for 10 positive items and 0.84 for 10 negative items on this scale. The alpha was found 0.93 for a total of 20 items. The fact that this value is between 0.71 and 1 shows that this scale is quite reliable. Besides these, the data was also collected by the open-ended questions which were created by the researchers and formed with the experts' opinions.

\section{Results}

3.1 Research Problem 1: Do the educational videos which were developed under E-Learning have an impact on the students' attitudes towards ELearning?

As it can be seen in Table 1 while the point average of the pretest is 53.63, the posttest point average has increased to 59.54. In order to find the significant differences, the Paired Samples $t$-test was performed and because $\mathrm{p}<0.05(\mathrm{p}=.002) \mathrm{t}$ was concluded that it is a significant difference. The significant difference between posttest and pretest is in favor of the posttest. 
İ. H. Özdemir, F. Sarsar \& Ö. Andiç-Çakir - The Effects of Educational Videos on Views and Attitudes ...

Table 1. The analysis results regarding pretest-posttest scores

\begin{tabular}{lcccccc}
\hline \multicolumn{1}{c}{ Test } & N & $\boldsymbol{X}^{-}$ & S & t & Sd & p $^{*}$ \\
\hline Pre-test & 50 & 53.64 & 8.75 & -3.299 & 49 & .002 \\
Post-test & 50 & 59.54 & 8.18 & & & \\
\hline
\end{tabular}

${ }^{*} \mathbf{p}<.05$

As it can be seen on Table 2, the least score between 1-10 for students learning environment is 4 and the highest score is 10. The point average regarding students' learning environment is 7.12 and the standard deviation is 1.45 . The least score between 1-10 regarding students' video material is 2 while the highest score is 10.

The point average regarding students' learning environment is 6.10 and the standard deviation is 1.96. And the least score between 1-10 regarding the level of putting what they have learned into practice through video materials is 2 while the highest score is 10 . The point average of students' learning environment is 6.42 and the standard deviation is 1.99 .

Table 2. Instructional material and environment scores

\begin{tabular}{ccccccc}
\hline $\begin{array}{c}\text { Scored } \\
\text { Status }\end{array}$ & $\mathbf{N}$ & $\begin{array}{c}\text { Minimum } \\
\text { Score }\end{array}$ & $\begin{array}{c}\text { Maximum } \\
\text { Score }\end{array}$ & Clearance & SS & Average \\
\hline $\begin{array}{c}\text { Learning } \\
\text { Environment }\end{array}$ & 50 & 4 & 10 & 6 & 1.45 & 7.12 \\
$\begin{array}{c}\text { Video } \\
\text { Material }\end{array}$ & 50 & 2 & 10 & 8 & 1.96 & 6.10 \\
$\begin{array}{c}\text { Put Into } \\
\text { Practice }\end{array}$ & 50 & 2 & 10 & 8 & 1.99 & 6.42 \\
\hline
\end{tabular}

3.2 Research Problem 2: How are the opinions of engineering undergraduate students towards educational videos which were developed regarding E-Learning?

The students were asked "How do you think the videos you have watched under this course affected your learning process?" The answers were shown in Table 3. In the light of the analysis, $26 \%$ of the students described videos as affirmative. Also, $24 \%$ of the students found them instructional. $18 \%$ of the students said that the videos increased readiness while $12 \%$ find them embodying. $12 \%$ said memorable and the other $12 \%$ viewed them as effective.

The views of the students are as follows:

S17: "Made me more prepared for class."

S18: "The videos I watched gave me a lot of information before the experiments and I was more prepared for them. The videos affected my learning process positively."

S32: "I find the videos beneficial. They contributed to the classes and the experiments we performed."

S28: "Watching the videos before class increased my motivation and learning efficiency. The things we see for the second time made them more memorable. The videos are a reference in itself while preparing the reports.” 
Table 3. Affecting the learning process

\begin{tabular}{lcc}
\hline $\begin{array}{l}\text { How do you think the videos you watched } \\
\text { in the course affected your learning } \\
\text { process? }\end{array}$ & f & \% \\
\hline Positive & 13 & 26 \\
Instructional & 12 & 24 \\
Enhancing Readiness & 9 & 18 \\
Facilitator & 8 & 16 \\
Embodying & 6 & 12 \\
Memorable & 6 & 12 \\
Effective & 6 & 12 \\
\hline
\end{tabular}

The students were asked "How do you think about the videos you have watched in the course to be the course material? The answers were shown in Table 4. In the light of the analysis, $80 \%$ of the students find the videos affirmative. $20 \%$ of the students find them reinforcing. $16 \%$ of the students in the research find them facilitative while $8 \%$ of them find them to be beneficial. $8 \%$ of the students viewed the videos as reliable.

However, $8 \%$ of the students find the videos negative while $4 \%$ of them find them insufficient. $4 \%$ of the students in the research viewed the videos as having a sense of obligation.

Examples of students' views are as follows:

S41: "I find it positive, we get information about our visual memory and I believe it is more permanent."

S17: "It is more beneficial and interesting to be like this than the written material."

S39: "I think it's a positive situation that allows us to learn about the experiment."

S10: "I find it efficient. Theoretically, knowledge is stuck somewhere. Watching how it is done increases the memorability."

Table 4. Opinion regarding the course material

\begin{tabular}{lcc}
\hline $\begin{array}{l}\text { What do you think about the videos } \\
\text { you watched in the course as used as } \\
\text { the course material? }\end{array}$ & f & \\
\hline Positive & 40 & 80 \\
Supportive & 10 & 20 \\
Facilitator & 8 & 16 \\
Permanent & 8 & 16 \\
Enhancing learning & 6 & 12 \\
Helpful & 4 & 8 \\
Reliable & 4 & 8 \\
Negative & 4 & 8 \\
Insufficient & 2 & 4 \\
The Feeling of Necessity & 2 & 4 \\
\hline
\end{tabular}

"Do you think the learning environment (Edpuzzle) where the course materials are shared was student-centered? Please explain." The question was asked, and the answers given are shown in Table 5 by showing the frequency. In the light of the analysis, $64 \%$ of the students defined the learning environment as student-centered. In addition, $18 \%$ of the students stated that the learning environment is not student-centered. While $16 \%$ of the students participating in the research stated that the learning environment is accessible, $14 \%$ were instructive, $14 \%$ interactive, 
İ. H. Özdemir, F. Sarsar \& Ö. Andiç-Çakir - The Effects of Educational Videos on Views and Attitudes ...

$14 \%$ applicable, $12 \%$ easy to use, $10 \%$ compulsory, $6 \%$ partially and $4 \%$ of them expressed their views on access to the learning environment.

Examples of students' views are as follows:

S1: "Yes. Students can manage the materials."

S31: "Yes, it was aimed at the student. It was simple to use, easy and convenient."

S48 "Yes, it provides great convenience in accessing course materials"

S4: "Yes. The application was very successful with easy access and the opportunity to watch the videos again.

Table 5. Views regarding the learning environment

\begin{tabular}{lcc}
\hline $\begin{array}{l}\text { Do you think the learning } \\
\text { environment (Edpuzzle) where the } \\
\text { course materials were shared was } \\
\text { student-centered? Explain. }\end{array}$ & & \\
\hline Yes & f & \% \\
Accessible & 32 & 64 \\
Instructive & 8 & 16 \\
Interactive & 7 & 14 \\
Applicable & 7 & 14 \\
Easy to Use & 7 & 14 \\
No & 6 & 12 \\
Required & 9 & 18 \\
Access & 5 & 10 \\
Partially & 2 & 4 \\
\hline
\end{tabular}

The question of "Complete the sentence as the video-supported materials progress at my pace..." was asked to the students and the answers given are shown in Table 6 by showing the frequency. In the light of the analysis, $42 \%$ of the students completed the sentence as "it enabled me to understand permanently." In addition, 26\% of the students completed it as "I learned easily." While $20 \%$ of the students participating in the study stated that their willingness to learn increased, 10\% stated that they provided course follow-up, 6\% stated that interaction increased and $4 \%$ stated that following was difficult.

Students completed the sentence as follows:

S32: "I watched the videos carefully and was able to make the necessary comments."

S31: "I had no trouble following."

S36: "I could learn the information in the video more easily."

S40: "I had the opportunity to rewind whenever I wanted." 
Table 6. Video course materials and individuality

\begin{tabular}{lcc}
\hline $\begin{array}{l}\text { Complete the sentence as "Video-supported } \\
\text { materials are progressing at my pace...". }\end{array}$ & f & \% \\
\hline It provided permanent understanding & 21 & 42 \\
I learned comfortably & 13 & 26 \\
Increases Learning Willingness & 10 & 20 \\
It provided me to track course & 5 & 10 \\
My Interaction Increased & 3 & 6 \\
It was difficult to follow & 2 & 4 \\
\hline
\end{tabular}

"What was the most interesting thing about the videos with Digital Course Material (DCM)?" and the answers given are shown in Table 7 by showing the frequency. In the light of the analysis, $26 \%$ of the students answered about the performance of the experiment. In addition, $16 \%$ of the students stated that it was interesting. $12 \%$ of the students participating in the study stated that they were interested in being a source of information, while $12 \%$ stated that they were interested in being course materials, $12 \%$ being able to turn into practice and $6 \%$ being comfortable.

Examples of students' views are as follows:

"The most interesting thing in the videos was the processing of the topics that exactly correspond to my future profession and their transfer to me already."

S37: "Showing the narrated objects together."

S9: "It was that it was accessible anywhere, anytime."

S13: "It was useful to see a subject that we covered in the course put into practice. It was especially interesting to watch the cement experiment."

S40: "The most interesting thing was that the experiments were done step by step and by establishing the cause-effect relationship in the videos which are digital course material."

Table 7. Student interest in digital course materials

\begin{tabular}{lcc}
\hline What attracted you the most about the & & \\
Digital Course Material (DCM) videos? & f & \% \\
\hline Experimental Procedure & 13 & 16 \\
Being Interesting & 8 & 12 \\
Being a Source of Information & 6 & 12 \\
Course Materials & 6 & 12 \\
Becoming a Practice & 6 & 6 \\
Being comfortable & 3 & \\
\hline
\end{tabular}

"Do you think DCMs are suitable for civil engineering? Why is that?" The question was asked, and the answers given are shown in Table 8 by showing the frequency. In the light of the analysis, $76 \%$ of the students answered yes. In addition, $20 \%$ of the students stated that they were instructors. $16 \%$ of the students participating in the study stated practical, $12 \%$ course reinforcement, $12 \%$ efficient, $6 \%$ modern, $6 \%$ no, $6 \%$ traditional learning and $4 \%$ visually.

Sample expressions from students' views are as follows:

S40: "It is appropriate, and it should be used more frequently in other courses. Civil engineers must be people who can think in $3 \mathrm{D}$ and envision events. These DCMs increase the visuals.” 
İ. H. Özdemir, F. Sarsar \& Ö. Andiç-Çakir - The Effects of Educational Videos on Views and Attitudes ...

S41: "Yes, I think it is suitable. Because it brings to mind a subject whose theory we see in the course with videos."

S7: "Yes, it is useful in seeing the experiment being done."

S2: "DCMs are suitable for every course, every engineering or department.

The ability to visualize and repeat information is a great advantage."

Table 8. Digital course materials in civil engineering

\begin{tabular}{|c|c|c|}
\hline $\begin{array}{l}\text { Do you think DCMs are suitable for civil } \\
\text { engineering? Why is that? }\end{array}$ & $\mathbf{f}$ & $\%$ \\
\hline Yes & 38 & 76 \\
\hline Instructive & 10 & 20 \\
\hline Practical & 8 & 16 \\
\hline Reinforcing & 6 & 12 \\
\hline Efficient & 6 & 12 \\
\hline Modern & 3 & 6 \\
\hline No & 3 & 6 \\
\hline Traditional Learning & 3 & 6 \\
\hline Visual & 2 & 4 \\
\hline Infrastructure & 2 & 4 \\
\hline Partially & 2 & 4 \\
\hline
\end{tabular}

"How did the instructor's use of this DCM affect your motivation for the Course? The question was asked, and the answers given are shown in Table 9 by showing the frequency. In the light of the analysis, $68 \%$ of the students stated that it affected positively. In addition, $44 \%$ of the students stated that it increases motivation. $18 \%$ of the students participating in the study stated that it increased learning, $12 \%$ was negative, $12 \%$ did not motivate, $10 \%$ was interesting, $4 \%$ was indecisive, and $2 \%$ provided focus.

Sample expressions from students' views are as follows.

S18: "It has increased my motivation for the course."

S41: "It made the course more interesting and added color to the existing order. Course lecture colored with visuals may be preferred than a course where we constantly see articles."

S14: "It has increased my motivation because it makes me understand more easily."

S32: "My motivation for the course has increased as we experience the theoretical information, we learned in the courses visually."

Table 9. Student motivation in digital course materials

\begin{tabular}{lcc}
\hline $\begin{array}{l}\text { How did the instructor's use of this DCM } \\
\text { affect your motivation for the Course? }\end{array}$ & f & \% \\
\hline Positive & 34 & 68 \\
It Increased My Motivation & 22 & 44 \\
It Increased My Learning & 9 & 18 \\
Negative & 6 & 12 \\
It did not motivate & 6 & 12 \\
Interesting & 5 & 10 \\
Hesitant & 2 & 4 \\
It made me focus & 1 & 2 \\
\hline
\end{tabular}




\section{Conclusion and discussion}

Within the scope of the research about the effects of educational videos on engineering undergraduate students' laboratory applications and its examination of opinions, the effect of educational videos and the developed learning environment on attitude towards e-learning in engineering education was examined. In addition, student views on the online learning environment developed were also examined within the scope of the research.

Today, engineering laboratory applications are supported by using technological tools such as videos, simulations, virtual reality applications. In our project, the laboratory applications of a course opened in the civil engineering department were prepared using appropriate techniques as video learning materials and digital course materials, and the student's attitude towards the digital course material was questioned through this sample material presented to the student. The pretest and posttest performed in this study were found to be significantly different in favor of the posttest as a result of the Paired Samples T test analysis $(\mathrm{p}=0.02)$. This result reveals that online learning environments and educational videos in engineering education positively affect students' attitudes.

This result supports the studies in the literature (Dharmadhikari, 2011; Kay \& Kletskin, 2012; Rhema \& Miliszewska, 2014; Chao, Chen \& Chuang, 2015). In addition, the students stated that they found $80 \%$ positive to the open-ended question asked about how they found the learning materials. This situation also showed that the students gained positive qualities in the process.

It was concluded that the students' average score for the learning environment used within the scope of this study was approximately 7 over 10. This shows that the students are satisfied with the learning environment above average. In addition, students' scores for educational video materials used as content in the learning environment appear to be approximately 6 . In the light of this scoring, it is concluded that the students are generally satisfied with the video materials. However, the level of applying what students learn from the online learning environment is about 6.5 out of 10.

Within the scope of this research, it was concluded that educational videos affect the learning process in a useful and instructive way. This result is in parallel with other studies in the literature (Simo et al., 2010; Violante \& Vezzetti, 2014; Granjo \& Rasterio, 2018). The use of educational videos prepared within the scope of the research as course material was welcomed by the students. In addition, the students found it safe to use educational videos as course material. This result supports the studies found in the literature (Jackson et al., 2013; Zaneldin, Ahmed \& El-Arris, 2019).

When the opinions about the learning environment used for the sharing of course materials within the scope of the research are examined, it is concluded that the learning environment is student-centered; The results are also accessible, instructive and interactive. When the opinions about the educational videos progress according to individual speed, it is concluded that individuality provides permanent understanding in students. In addition, it was concluded that the students could easily perform the learning process and their willingness to learn increased. This result fits with other results in the literature (Dharmadhikari, 2011; Wagner, Laforge \& Cripps, 2013; Violante \& Vezzetti, 2014; Carbonell \& Pons, 2014; Granjo \& Rasterio, 2018). Transferring the experimental processes carried out in engineering education with educational videos will increase the attractiveness of the Digital Course Material. However, it was concluded that these Digital Course Materials are suitable for civil engineering laboratory education. The factors affecting this eligibility are being instructive, practical, reinforcing and efficient. 
İ. H. Özdemir, F. Sarsar \& Ö. Andiç-Çakir - The Effects of Educational Videos on Views and Attitudes ...

The instructor's use of educational videos, which are Digital Course Materials, positively affects the motivation of the students to the course. This result is in line with other studies in the literature (Dharmadhikari, 2011; Wagner, Laforge \& Cripps, 2013; Violante \& Vezzetti, 2014; Carbonell \& Pons, 2014; Månsson, Löfgreen \& Warfvinge, 2017).

It is expected that the results of the study will be facilitated by the help of digital course materials, primarily for the relevant courses of our engineering faculty, and then in our other laboratories serving these faculties. In the light of the results of this study, it is recommended to conduct a wider study with the participation of other relevant units, especially in engineering education. The work outcomes are important in terms of interdisciplinary impact in education and engineering.

The outputs of this research are also important in terms of helping/supporting the production and sharing of ready-made materials against unexpected situations such as pandemic (epidemic) periods.

\section{Acknowledgements} Coordination.

This project (ID: 18-BİL-008) was fund by Ege University Scientific Research Project

The authors declare no competing interests.

\section{References}

Alkan, V., Şimşek, S., \& Armağan Erbil, B. (2019). Hash method: Story field print review. Journal of Qualitative Research in Education, 7(2), 558-581. https://doi.org/10.14689/ISSN.21482624.1.7c.2s.5m

Brame, C. J. (2016). Effective educational videos: Principles and guidelines for maximizing student learning from video content. CBE-Life Sciences Education, 15(4), es6.

Büyüköztürk, Ş., Çakmak, E. K., Akgün, Ö. E., Karadeniz, Ş., \& Demirel, F. (2017). Scientific research methods. Pegem Akademi.

Carbonell, M. R. E., \& Pons, J. V. (2014, October). Open educational resources for enhancing the learning of calculus in engineering education: Last improvements: Televoting system and specific thematic math videos. In 2014 IEEE Frontiers in Education Conference (FIE) Proceedings (pp. 1-8). IEEE.

Chao, C. Y., Chen, Y. T., \& Chuang, K. Y. (2015). Exploring students' learning attitude and achievement in flipped learning supported computer-aided design curriculum: A study in high school engineering education. Computer Applications in Engineering Education, 23(4), 514-526.

Creswell, J. W. (2009). Research design: Qualitative, quantitative, and mixed methods approaches (3. Baskı). Thousand Oaks, CA: Sage.

Dharmadhikari et al. (2011). Create educational lesson videos compatible with the streaming server using low-cost resources. IEEE International Educational Technologies Conference (pp. 116-120). IEEE.

Domingues, L., Rocha, I., Dourado, F., Alves, M., \& Ferreira, E. C. (2010). Virtual laboratories in (bio) chemical engineering education. Education for Chemical Engineers, 5(2), e22-e27. 
Fernandez, V., Simo, P., Algaba, I., Albareda-Sambola, M., Salan, N., Amante, B., ... \& Rajadell, M. (2011). Low-cost educational videos' for engineering students: a new concept based on video streaming and Youtube channels. International Journal of Engineering Education, 27(3), 518.

Ferreira, E. C. (2004). Blended learning in bioprocess systems engineering education: issues, methods, and applications. In ESCAPE-14: European Symposium on Computer-Aided Process Engineering (pp. 16-19).

Fiorella, L., \& Mayer, R. E. (2018). What works and doesn't work with instructional video. Computers in Human Behavior, 89, 465-470.

Granjo, J. F., \& Rasteiro, M. G. (2018). LABVIRTUAL-A platform for the teaching of chemical engineering: The use of interactive videos. Computer Applications in Engineering Education, 26(5), 16681676.

Haznedar, Ö., \& Baran, B. (2012). A study to develop a general scale of attitude towards e-learning for education faculty students. Educational Technology Theory and Application, 2(2), 42-59.

Iqbal, S., Zang, X., Zhu, Y., Chen, Y. Y., \& Zhao, J. (2014, December). On the impact of MOOCs on engineering education. In 2014 IEEE International Conference on MOOC, Innovation, and Technology in Education (MITE) (pp. 101-104).

Jackson, N., Quinn, D., Lonie, A., Rathore, P. \& James, P. (2013). Video in engineering courses to promote active online learning environments. In Proceedings of A2E2 conference Gold Coast. Online access: $\quad$ https://www.engineersaustralia.org.au/australasian-association-engineeringeducation/2013-annualconference.

Kay, R., \& Kletskin, I. (2012). Evaluating the use of problem-based video podcasts to teach mathematics in higher education. Computers \& Education, 59(2), 619-627.

Kerr, B. (2015, September). The flipped classroom in engineering education: A survey of the research. In 2015 International Conference on Interactive Collaborative Learning (ICL) (pp. 815-818). IEEE.

Kleftodimos, A., \& Evangelidis, G. (2018, April). Augmenting educational videos with interactive exercises and knowledge testing games. In 2018 IEEE Global Engineering Education Conference (EDUCON) (pp. 872-877). IEEE.

Maclaren, P. (2018). How is that done? Student views on resources used outside the engineering classroom. European Journal of Engineering Education, 43(4), 620-637

Månsson, J., Löfgreen, J., \& Warfvinge, P. (2017). Effective use of video in engineering education. In 6: $e$ Utvecklingskonferensen för Sveriges ingenjörsutbildningar, Chalmers tekniska högskola, 2223 November 2017 (pp. 94-96). Chalmers tekniska högskola.

Marques, J. C., Quintela, J., Restivo, M. T., \& Trigo, V. (2012, September). The use of video clips in engineering education. In $201215^{\text {th }}$ International Conference on Interactive Collaborative Learning (ICL) (pp. 1-4). IEEE.

Mayer, R. E. (2009). Multimedia learning. Cambridge: Cambridge University Press.

Nguyen, K. A., Husman, J. E., Borrego, M. J., Shekhar, P., Prince, M. J., \& Demonbrun, M. (2017). Students' expectations, types of instruction, and instructor strategies predicting student response to active learning. AERA Online Paper Repository.

Pedrotti, M., \& Nistor, N. (2014, July). Online lecture videos in higher education: Acceptance and motivation effects on students' system use. In 2014 IEEE $14^{\text {th }}$ International Conference on Advanced Learning Technologies (pp. 477-479). IEEE.

Rhema, A., \& Miliszewska, I. (2014). Analysis of student attitudes towards e-learning: The case of engineering students in Libya. Issues in informing science and information Technology, 11, 169190. 
İ. H. Özdemir, F. Sarsar \& Ö. Andiç-Çakir - The Effects of Educational Videos on Views and Attitudes ...

Saar, M., Kusmin, M., Laanpere, M., Prieto, L. P., \& Rüütmann, T. (2017, April). Semantic annotations and teaching analytics on lecture videos in engineering education. In 2017 IEEE Global Engineering Education Conference (EDUCON) (pp. 1548-1551). IEEE.

Shephard, K. (2003). Questioning, promoting, and evaluating the use of streaming video to support student learning. British Journal of Educational Technology, 34(3), 295-308.

Simo, P., Fernandez, V., Algaba, I., Salan, N., Enache, M., Albareda-Sambola, M., ... \& Rajadell, M. (2010). Video stream and teaching channels: quantitative analysis of the use of low-cost educational videos on the web. Procedia-Social and Behavioral Sciences, 2(2), 2937-2941.

Toto, R., \& Nguyen, H. (2009, October). Flipping the work design in an industrial engineering course. In $200939^{\text {th }}$ IEEE Frontiers in Education Conference (pp. 1-4). IEEE.

Violante, M. G., \& Vezzetti, E. (2014). Implementing a new approach for the design of an e-learning platform in engineering education. Computer Applications in Engineering Education, 22(4), 708-727.

Wagner, D., Laforge, P., \& Cripps, D. (2013). Lecture material retention: A first trial report on flipped classroom strategies in electronic systems engineering at the University of Regina. Proceedings of the Canadian Engineering Education Association (CEEA).

Wilkinson, A., Roberts, J., \& While, A. E. (2010). Construction of an instrument to measure student information and communication technology skills, experience, and attitudes to e-learning. Computers in Human Behavior, 26, 1369-1376.

Yang, D., \& Pakala, K. (2017). Building an effective online thermodynamics course for undergraduate engineering students. Online assess: https://scholarworks.boisestate.edu/cgi/viewcontent.cgi?article=1169\&context=edtech facpu bs.

Zaneldin, E., Ahmed, W., \& El-Ariss, B. (2019). Video-based e-learning for an undergraduate engineering course. E-Learning and Digital Media, 16(6), 475-496. 